\title{
RELIGIOUS TOURISM: AN INSIGHT INTO THE ISLAMIC TOURISM OF TABLIGHI JAMAAT
}

\author{
Rameez Ahmad Lone \\ Senior Research Fellow \& Assistant Professor Contr., Department of Sociology, \\ GDC Sopore J \& K - 193198
}

Article DOI: https://doi.org/10.36713/epra8443 DOI No: 10.36713/epra8443

\begin{abstract}
Islam is not merely the set of religious rituals or beliefs but a complete way of life. There is not even a single matter, no matter how peculiar, awkward or dull it may seem, about which Islam does not deals or directs. In all behind every act, including tourism, there is sole purpose seeking the pleasure of God-Almighty Allah, by following His commandments. Islam encourages travel or tourism and hospitable behavior, and unlike west connects it with the most sublime and honorable values and morals. It is in this backdrop, the focus of the present study is 'Tablighi Jamaat'- an Islamic revival movement, founded by Maulana Ilyas in Mewat region near Delhi-India, around 1920's. This movement has come to establish its presence surprisingly in and over one hundred and fifty countries throughout the world with a large number of adherents in between 100 to 150 million. This is principally, because of its unique 'travel and tourism' approach, which it has adopted as a daw'ah (invitation towards Islam) methodology. Consequently and interestingly, because of this fact 'the travel and tourism approach,' the movement has also been named as 'travelers in faith'. This paper is primarily based on secondary sources and the main objective of the paper is to provide an insight into the religious tourism of Tablighi Jama'at.
\end{abstract}

KEY WORDS: Islam, Religious Tourism, Tablighi Jamaat, Tourism, Travelers.

\section{INTRODUCTION}

Islam and tourism are complimentary and not contradictory. The two are mutually reinforcing. However, the goals of tourism and travel in Islam are quite contradictory, to the goals of modern tourism industry especially the western, which primarily focus on more and more profit, without caring its evil effects or dark side like sex tourism, prostitution, gambling, alcoholism and other environmental impacts. Islam encourages travel or tourism and hospitable behavior, and unlike west connects it with most sublime and honorable values and morals. The main purpose of travelling in Islam besides spreading the word of Allah (or Islam), is to attain spiritual, social and physical goals. The verses of the Quran which deal with travel and tourism are: Al-Naml (The Ant): 69; Al Nahl (The Bee): 36; Al-Imran (The Amramites): 137; AlAnkaboot (The Spider): 20; Al-An'am (The Livestock): 11; Al-Room (The Romans): 42/9; Ghafer (Forgiver): 82/21; Saba' (Sheba): 18; Muhammad:10;
Al-Mulk (Kingship): 15; Younus ( Joseph): 109; AlHajj (The Pilgrimage): 46; and Faater (Initiator): 44 (Yousuf Ali, 2005; Pickthall, 1976). The main lessons are that the beauty and bounty of God-Allah's creation enhances in submitting oneself completely to GodAlmighty Allah, by reinforcing ones belief in Allah and in His greatness. Feeling weak or grasping the smallness before the greatness of God-Allah, in His creations improves faith in God-Allah. Travel or tourism enable Muslims to serve God happily and better, because it reduces stress on the one hand, and improves one's health and well being on the other. It is also one of the main ways to acquire knowledge which is obligatory in Islam for every men and women and is a test of perseverance and patience ((Zamani-Farahani \& Henderson, 2010). According to Quran, the holy text of Islam, Muslims should travel so that they can grasp and appreciate the beauty of Almighty Allah's world; and also visit their relatives and friends. Besides they must provide hospitality to the tourists or visitors who, 
under Islamic Shariah (Islamic code of conduct) enjoy certain rights. (Okhovat, 2010).In addition to the above, the 'dawa' ${ }^{1}$ and seeking knowledge' ${ }^{2}$ which are obligatory upon every Muslim, men and women, young or old is impossible and incomplete, without some travel.

Thus, 'Tablighi Jamaat'- a dawah or religious revival movement among Muslims have adopted 'tour and travelling' as their basic method in its call towards Islam. Maulana Mohamad Ilyas required strictly from his Tablighi activists and followers that:

(i). They should 'tour' their neighbourhoods, and thereby must invite the people of their locality towards Islam. There they must preach about the fundamental principles of religion like 'Kalimah' ${ }^{3}$ and Prayers. For this to be practised daily a proper method should be formed under the direction of a leader.

(ii). That in every month, for preaching, Mewati's ${ }^{4}$ or Tablighi activists should spend three days in travelling up-to a distance of five kilometres- which was referred as 'kos' or 'panch kosa' in Mewati parlance. There they should persuade local people to take 'similar tours' for the preaching.

(iii). That they should spend forty days (also called one chillah) every year in 'Tablighi tour' for their learning and propagation of basic teachings of Islam among their fellow Muslims, and;

(iv). That they should spent, at least four months or three chillah's once in a life for 'tablghi work' and should leave their homes for the learning and study of Islam (Haq, 1972).

From above, it seems clear, that 'Tablighi Jamaat' is nothing but a 'travelling and touring group' which travel for the propagation or renewal of basic fundamentals of their religion- Islam, among their fellow Muslim brothers. Thus they provide a unique instance of 'religious tourism' A brief and precise discussion of their, origin, principles and methods of working in the light of 'travel and tourism approach' is given in the following pages.

$1 \quad$ http://aboutislam.net/counseling/ask-thescholar/dawah-principles/giving-dawah-obligatory/ 2 . http://www.quranreading.com/blog/importance-ofseeking-knowledge-in-islam/

3 . Kalimah which means, that 'there is no God, but Allah and Prophet Muhammad is His last messenger'. Its sometimes also called as word of 'shahada' or testimony.

${ }^{4}$.Mewatis or Meos, are the residents of the Mewat region of Haryana, among whom Maulana Ilyas started his Tablghi project in 1920's.

\section{TABLIGHI JAMAAT}

Tablighi Jamaat is one of the most prominent Islamic missionary movements of $20^{\text {th }}$ century Islam. The organization is said to be having a presence in between 150 to 200 countries, with its estimated adherents numbering between twelve million to one hundred fifty million, the majority of which are living in South Asia. It primarily focuses on making Muslims better and purer Muslims, and are having least concern in inviting non-Muslims to Islam. They are of the view that is quite illogical and irrational to preach others towards Islam, when Muslims are themselves not truly practising their own religion. So their prime focus is on the "renewal and rejuvenation of faith among their own fellow Muslims, through tabligh and through the 'novel method' of 'travel and tourism'.

\section{ORIGIN}

The 'Tablighi Jamaat' was founded by Maulana Muhammad Ilyas in 1920's and was formally launched either in 1926, or 1927.This movement came as a reaction against Shuddi and Sanghathan threat- which were busy in converting nau-Muslims to Hinduism. These Hindu revival movements were at peak in early $20^{\text {th }}$ century and its leaders were not only calling to 'forceful conversion' of all Indian Muslims but were 'openly' branding Islam as a 'bloodthirsty' religion. It is said, that these Hindu revival movements were successful to a large extent in conversion of neoMuslims back to Hindu fold. It's in this approximate context, Maulana Ilyas Muhammad 'travelled' to Mewat and started its 'dawa'ah' project among the Meos of Mewat (neo-Muslims) who were still practising their Hindu accredited customs or traditions, and which were under constant threat of Hindu revival movements. In the beginning, Ilyas is said to have formed various 'madrasas' (religious schools) for his 'dawah project' and among the Mewati's, but was soon disappointed with his 'madrasa experience' which to him were producing mere 'religious functionaries' and not 'religious preachers' as he desired. So he opted for 'travel and tour' method, for direct and oral preaching among the Mewati's and enjoined his followers to follow the same method among the other Muslims (Sikand, 2002; Lone, 2018; Agwani, 1986 )

However, the inspiration to launch the movement and to devote his life for preaching of Islam at the grass- roots level through travel and by visiting door to door came to Ilyas during his 'second pilgrimage' to Hijaz-Mecca in 1926. According to one chronicler of the movement, the principles of the 'tabligh' were conveyed to Ilyas by divine revelation in the course of his sojourn in Mecca. On his return to 
India, Ilyas started the practice of undertaking 'preaching tours' and invited others to do likewise (Agwani, 1986:41).

\section{PRICNCIPLES}

In its preaching 'tour and travel' the members of the Tablighi Jamaat are required to follow a certain set of six ideological principles' while presenting the dawah message before Muslims. These 'six principles' are called 'chaii baatien' (six talks) in tablighi terminology. Similarly, Rameez Ahmad, mentions, Ilyas had advised, to form a mobile units of around ten persons which are required to 'travel or visit' to various places and would present their message in the light of 'six principles' principles' in order to improve the knowledge and faith of the local Muslims(Lone, 2018). These principles are:

1. 'Kalima' or Shahadah' (which literally means testimony, but here refers to the verse of the Quran which says: 'there is no god, but God 'Allah' and Muhammad is His messenger'). The recite of the Shahadah will eventually be obliged to ascertain God's commandments on all matters concerning ones daily life.

2. 'Namaaz' or prayers. Muslims offer five times obligatory prayers daily. Tablighi activists are required to observe strictly prayers and are advised to call the local people to practice the same. In this principle members of the tablighi are instructed and learned about its various rules and composition.

3. 'Ilm and Zikr' (which means knowledge and remembrance of God-Allah respectively). Attaining knowledge is obligatory in Islam and 'zikr' 'remembrance of Allah' is the best way to cultivate the 'love of God Almighty Allah'. The practice of zikr purifies the heart and also increases knowledge. Various types of ' $z i k r$ ' are recommended in Tablighi literature, for its activists to practice.

4. 'Ikram-i-Muslim' (respect for faithful or Muslim). A Muslim must show respect for and courtesy to fellow Muslims. A hate, grudge or being envious to Muslims is strictly objected.

5. 'Ikhlaas-i-Niyat' (sincerity of 'intention'). All good works like worshipping Allah or praying must be motivated by the wish or desire to please Allah alone and not to gain any public reputation or recognition.

6. 'Taffrig-i-waqt' (means sparing of time). According to this principle Tablighi activists in particular and all Muslims in general must spare time in preaching and inviting people towards
Islam. This principle is also called 'dawat-otabligh' that is, 'inviting and preaching'.

The sixth principle is the most important principle, because when this principle is practised, all other principles follow logically. When one spent's time or 'travels and tours' with the Tablighi Jamaat to various places, he naturally learns meanings and demands of other principles in the company of tablighi activists under the daily direction of 'Ameer' or head (Haq, 1972; Agwani, 1986; Lone, 2018; Khan, 1986).

\section{METHOD OF WORKING}

The Maulana's method of working for this goal 'of reviving the faith and fostering the relationship with God-Allah' was very simple. It was to revive the activities of the mosques on the pattern of the early days of Islam. 'Movement and travel' were greatly emphasized, as a means to make people truly religious. People were to be withdrawn for a time from their daily chores to share in the religious environment. There they were trained to urge others to follow the same path (undertaking preaching tours). And, when they returned home they were expected to retain their impression for a long time. It was expected that the religious and spiritual lessons, they had been taught, would be pursued by them in the mosques of their neighbourhood. This mosque oriented life 'travelling from mosque to mosque' in itself as the Maulana saw it, would ensure success in both the worlds.

Besides regarding travelling for dawah, he explained his point of view in a letter to one of his followers: "To learn to lead a truly religious life, whatever the sphere one belonged to, one was required to spare four months out of one's worldly engagements. During this period of travelling one had to preach the word of the God-Allah to all those, one came in contact with, on journeys to various places in and outside the country. The prophet's companions had thrown themselves into the performing of this task with total dedication. Their activities centred on mosques, where they talked of the greatness of God-Allah which strengthened them in their faith. It was in the mosques that they learnt how to purify their actions. It was there that the fact that they were accountable to God-Allah for their deeds was indelibly impressed upon them. It was in the mosques also that the missionary groups were formed. People from all the walks of life gathered to remember the God-Allah in the mosques and came in contact with one another there. Now we must set ourselves the task of preparing others to share this responsibility of indoctrinating others with religious truths alongside their secular education. After having performed the outdoor activities they should not forget the learning they have gained in the process of 
teaching, and they must continue those activities in the mosques of their own areas. It's our bounden duty to draw their attention towards this gigantic task. At least one person in each family should devote a part of his time to this job. Such people should work in unison. The local parties must visit different local mosques in turn to impart religious education to those assembled therein. This will create an environment for religious activities. Afterwards they should cover and travel the mosques, situated outside their own settlements. The mosques situated at a distance should be visited once a month and their stay there should be for at least three days in the month. Almighty God Allah will generously reward them for these three days, the reward equal to thirty days of work. Those who devote three days to such work every month will be reckoned by God Allah as having served for the whole year (Khan, 1986). Likewise, Mumtaz Ahmad (Ahmad, 1991) mentions, "The method devised by Maulana Mohammad Ilyas was to arrange mobile units of at least ten persons and send them to various villages. These 'Tablighi' units, or groups, would travel a village and request the local people to assemble in the mosque, if there was one, or at any other meeting place, and would present their message in the form of the six demands". While in Tablighi Jamaat, the members are required and instructed to spend at least three days in a month, forty days, in a year and four months once in a life while 'travelling' with the Jamaat. Besides, they do not just make religious trips at local, village or state levels, but also travel from country to country and continent to continent.

According to the plan and method evolved by Maulana Ilyas, a preaching team must have an Ameer (leader), Mutakalim (speaker) and a Rahbar (guide). The size of the team may vary between a maximum of ten and a minimum of three members. An average team must contain both instructors and learners. The 'Ameer' of course, provides leadership. He, however, must consult his colleagues, look after their needs and must inculcate among them an attitude of modesty. Everyone who could speak on the matter of the tabligh must have an opportunity to do so. The 'Ameer' might appoint a speaker or may do the job himself. If the speaker made a mistake while talking to individuals and groups in the target area, it was then, the responsibility of the 'Ameer' to correct him in a discreet manner. The speaker's task is to invite the Muslims of the target area to faith and to right conduct in as persuasive as a manner as he was capable of. The main emphasis, however, was to be on instructing people on how to perform ritual prayers and read the Quran correctly. Those of the team who knew should concentrate on teaching; and those who did not, on learning. The guide, for this part, concerned himself with practical arrangements such as travel and cooking and others chores (Agwani, 1986).

Thus Ilyas laid down various guidelines for these 'travelling' preaching teams. Besides, he believed that the work of religion could be promoted only by participating in the preaching tours and not by donating money. He, therefore, laid it down as a rule that each member of the preaching team should pay for his own travel and board. He was of the view that travel and emigration involve hardship, sacrifice and selfabnegation for the sake of God Allah's cause, and thus entitle one to divine succour (ibid, 43; Zainuddin, 2020).

\section{CONCLUSION}

In Islam it is not only permissible but religious obligation to tour and travel for spreading the message of Islam. Tablighi Jamaat- an Islamic, faith renewal movement provides a unique example such religious tourism' in the $21^{\text {st }}$ Century. The founder of the movement namely Maulana Muhamad Ilyas made 'travel and tour' the fundamental principle of the Jamaat. It's primarily because of this principle that the 'Tablighi Jamaat' has become one of the prominent Islamic movements throughout the world.

In this article, an attempt has been made to explore the religious tourism of 'Tablighi Jamaat'. It has been found that, 'travel and tourism' is one of the fundamental principle and method of 'Tablighi Jamaat' in its invitation to Islam. On the basis of this principle and the 'much importance' they attach to it, one can plainly and precisely name them as 'travelers in faith'. Thus in nut shell, one can conclude that Tablighi Jamaat provides a unique example of Islamic religious tourism in the $21^{\text {st }}$ century.

\section{REFRENCES}

1. Agwani, M. . (1986). Islamic Fundamentalism in India. Chandigarh: Twenty-First Century India Society.

2. Ahmad, M. (1991). Islamic Fundamentalismin South Asia: The Jam'at-i-Islami and the Tabligi Jamaat of South Asia. In M. E. Marty, R. S. Appleby, \& S. Asia (Eds.), Fundamentalisms Observed. Chicago and London: Univrrsity of Chicago.

3. Bulandsahri, M. A. E. (1989). Six Fundamentals of Tabligh. New Dehli: Idara-i-Isha'at-i-Diniyat.

4. Haq, S. A. (1972). The Faith Movement of Maulana Mohammad Ilyas. London: George Allen and Unwin.

5. Kadir, H.Din. (1989). Islam and Tourism: Patterns, Issues and Options, 16(4), 542-563.

6. Khan, W. (1986). Tabligh Movement. New Dehli: 
the Islamic Centre.

7. Lone, R. A. (2018). Tablighi Jamaat: Ideological Structure, 8(1), 1001-1011.

8. Masud, K. (2000). Travellers in Faith: Studies of the Tablighi Jama'at as a Transnational Islamic Movement for Faith Renewal. Brill: Leiden.

9. Nadwi, S. A. H. A. (n.d.). Ilyas aur Unki Deni Daw'at. Deoband: Kutub Khana

10. Okhovat, H. (2010). A Study on Religious Tourism Industry Management, Case Study: the Islamic Republic of Iran, International Journal of Academic Research, Vol. 2. No. 5. September 2010

11. Pickthall MW. (1976). The Glorious Quran (English \& Arabic). Taheike Tarsile Quran Inc. Elmhurst, New York.

12. Sikand, Y. (2002). The Origins and Development of the Tablighi Jama'at (1920-2000). New Dehli: Orient Longman.

13. Yusuf Ali A. 2005. The Meaning of the Holy Quran. Secretariat for Asia Assembly of Ulama: Selangor.

14. Zamani-Farhani, H., \& Hendeson, J.C (2010). Islamic Tourism and Managing Tourism. Development in Islamic Societies: The cases of Iran and Saudi Arabia. International Journal of Tourism Research, 12(1), 79-89.

15. Zainuddin, S. (2020). Some Aspects of Society and Religious Movement among Muslims "The Case of Tablighi Jamaat in Orissa." Publications Division, Aligarh Muslim University. 